su criterio político, tiene generosa benevolencia para juzgar a sus antiguos adversarios.

No siempre los recuerdos coinciden completamente con los hechos y a veces el señor Lastarria se ve obligado a hacer graves sacrificios a la tesis política que desenvuelve en su libro; pero, ese trabajo pone de relieve la devoción al estudio de su autor y rara aptitud de ir progresando y modificando su criterio con una frescura juvenil, aun en los últimos años de una vida larga y trabajada.

Partiendo de estudios y concepciones metafísicas, llega al positivismo de la escuela filosófica de Comte; partiendo de Ahrens llega a Mill. ¡Hermosa y rara facultad que pone en evidencia la amplitud de su talento y tenacidad con que perseguía su desarrollo intelectual! - $A$ U G U S T O $O$ R R E G O L Uc 0 .

Revista del Progreso.-Tomo IV.-Santiago 1890.-Págs. 101 a 150.

\title{
MEDINA Y LA HISTORIOGRAFIA AMERICANA
}

UN ENSAYO SOBRE LA APLICACIÓN DEL MÉTODO

$\mathrm{SO}$

N harta frecuencia obsérvase que poco hay tan ocasionado

a falsas interpretaciones como la aplicación del método en las ciencias. No obstante, nada parece más sencillo, sobre todo, si se conoce la universalidad de las leyes que rigen los fenómenos científicos. El proceso mental de la observación y de la inducción para llegar a establecer los principios generales del conocimiento, apenas se convierte en método, en sistema, en doctrina, no deja de tener, en la mayor parte de las veces, algún vicio de raciocinio que los filosofos y los matemáticos han llamado, en forma hasta cierto punto paradojal, cálculo de las probabilidades del error.

Si tales desvaríos pueden deslizarse en algunas ciencias cuya causalidad es invariable, por haberlo así demostrado la experimentación y la comprobación directa, calcúlese de cuanta trascendencia serán los quebrantos del razonamiento en el dominio de las ciencias históricas. El método en ellas es siempre problemático. Carece de leyes inmutables. No existe lo fenomenal, y el raciocinio es movible como la arena. Toda conclusión es puramente transitoria, como que queda reducida 
al sentido voluble de la interpretación del hombre, dominado por el incentivo ardiente de sus pasiones y sentimientos.

Casi siempre la historia adopta las formas del pensamiento de cada época. Ayer fué escuela de moral. Más tarde fuente de enseñanza política y social. Hoy se orienta hacia el sentido económico. Es decir, responde a las inquietudes espirituales del momento. ¿Qué será mañana?

Sus métodos, por otra parte, puramente objetivos, solo ponen a prueba la bondad y solidez del criterio del que los usa para inferir del hecho incompleto y fragmentario que arroja un documento mutilado, la adivinación, por decirlo así, de la que debió ser la verdad meridiana. Ni la heurística ni la hermenéutica pueden dar las formas definitivas del conocimiento exacto de un suceso. Solo nos aproximamos a él después de un largo proceso en la depuración de las fuentes, en el cotejo de los textos, en la valorización del testimonio presencial y en el examen riguroso de la documentación. Uno piensa que Renan, al llamar a la historia «ciencia de las probabilidades estaba en lo cierto, porque, precisamente, si hay algo incierto, es el método en ella.

Nada más complejo que la aplicación del método en lo que se ha dado en llamar la historia de América. Es quizás en toda la historia de la civilización moderna, el más difícil de llegar a establecer. Los elementos que debieron servir para fijarlo, para desentrañar el fondo de verdad de los sucesos, o se han perdido o śblo los conocemos por vagas y remotas referencias. O bien han permanecido sustraídos, hasta hace poco, a la compulsa de una crítica severa, 0 , por último, el espíritu brutal de la pasión, ha enturbiado la posibilidad certera de un juicio.

Así en el libro como en el documento. Y acaso la pasión sea lo más grave. La raza de gigantes que iba a iniciar en el siglo XVI la epopeya del descubrimiento y conquista del continente nuevo, se nos presenta ahora, con todo su extraordinario relieve de heroicidad, como la más henchida de tormentosos sentimientos. La mueve el orgullo, que es como una lacra que domina todo el vasto y magnífico escenario donde desenvuelve su obra. La agita el misticismo, que confunde la virtud cristiana con el crimen. La religiosidad fanática de la cruz se auna con el elemento civil y el clerical para alzar la palabra divina del perdón en el instante mismo del sacrificio. La superioridad moral de su fuerza avasalladora, no nos dej6 entrever en toda su amplitud el fenómeno social de las poblaciones autóctonas. Las destruye. Las aniquila. Incendia y extermina las preciosidades 
de sus templos religiosos, donde flotaba el sentimiento trágico de una civilización que se nos ha ocurrido llamar bárbara.

El español conquistador está dominado por el violento impulso de la arrogancia. Es la arrogancia castellana que va de lo heroico a las formas mansas de lo estoico. Hasta en el efectismo literario esa arrogancia encuentra formas de manifestarse. ¿Para qué hablar aquí del pundonor caballeresco, prolongación del ideal de la Edad Media? En su nombre el español conquistador nos deja ejemplo de desprendimiento y bizarría moral, dignos de un romano. También, cuando asume la representación del derecho se coloca en una situación extrema. La ley suprema de la monarquía de Castilla, aquella ley que hace la autoridad intangible, porque es el dogma de la majestad real, superior al hombre, inmanente, impera como un mandato brutal. Ni convence ni razona: obliga. El conquistador desprecia por eso las vidas ajenas y apenas si cuida la suya. Esa ley es tan rígida, tan violenta, tan cruel, que en manos del togado tiene siempre un dilema: o es arbitraria, o se inclina a un ciego favoritismo. De este modo, en virtud de las actitudes tiranas de la ley, ei hombre de la conquista se torna levantisco, indisciplinado, ferozmente individualista. Ahoga su conciencia en el placer de la venganza. Sólo se disciplina cuando forma levas dispuestas a realizar epopéyicas hazañas para la conquista de un fabuloso eldorado. Y no falta, sin embargo, en este cuadro de rapacidad, un romántico que busque una fuente de Juvencio.

«Aquí-decía el viejo La Gasca-no hay manera de sujetar los hombres. Tienen así como hambre de poder y de riqueza. Todo lo maltratan por estas cosas tan pasajeras. Y uno como vuestro leal vasallo, sblo quiere ordenar la tierra de estos hombres, que ya en el desenfreno, ni a V. M. quieren *. El obispo fray Diego Humanzoro escribía al Rey ya en plena colonia chilena: «Vuestros vasallos mienten porque les conviene aumentar sus hazañas, y también porque el diablo les ha hecho creer que mintiendo son más grandes a los ojos de los hombres humildes. Nadie dice la verdad porque les parece como cosa temeraria*. Y el virrey Hurtado de Mendoza ¿no hablaba de que ela malicia queda más maliciosas, (textual), en los procesos y relaciones de los soldados, oidores, curas y magistrados? $Y$ un santo, el arzobispo de Lima, Santo Toribio de Mogrovejo, le hablaba así al rey para persuadirlo, con sus palabras ingenuas, de la maldad de las gentes: « Mire V. M. que los hombres parecen venidos del infierno y las mujeres de aquel hondo lugar, porque no hay licencia que no cometan contra la verdad de Dios y de la Tierra, que en fin, por la lejura de Dios de ellos, no sería de tanta gra- 
vedad la ofensa, como por la Tierra que pisan ofendiéndola, que pudiera tragarlos, sin esperanza de hacer cosa de justicia. Y es que viven de tal manera asidos a los odios y a la envidia, a las maldiciones e infamias, los unos con los otros, que nadie quiere ensalzar al otro porque en esto les va algo así como la mesma vida».

Así es todo el largo proceso de la historia de América, porque así es la psicología brava de sus hombres. Es un puño fuerte de opresión y una estela de sangre. La verdad parece ocultarse en las largas sabanas. Se la lleva la corriente torrentosa de los ríos increíbles. Se escurre por las altísimas montañas del Andes, o se anida perdida en las rumorosas florestas de los trópicos. Sólo queda en las ciudades (en la plaza de armas, en el claustro, en los cuarteles, en los tribunales y en el solio del magistrado), el sordo murmullo de la envidia, del rencor. Hasta en la casona que sirve de hogar, acecha la impostura y la calumnia. La lujuria naturalmente tiene también su parte. Frailes solicitantes, se atrincheran en el confesonario; oidores enamorados burlan doncellas; militares aguerridos se amanceban con la india triste y dócil. Como para hacer más siniestro el cuadro de esta enturbiada época, siempre asoma en todas partes el calesín verde de la Inquisición. Evocadora de tormentos, de amargos procesos, al paso del carruaje, las gentes sienten el hielo de la muerte. El solo nombre del Santo Tribunal les horroriza. Las inquietudes intelectuales sólo vibran en los poetas culteranos, en los historiadores amantes de la tierra, en el novenario perenne que llena las prensas coloniales. Por eso, ninguna historia existe, como esta de América, con más singular relieve de emoción. Los tonos no tienen gamas intermedias. Contrastan bruscamente. Aquí nació la tragedia moderna con más virtualidad en la parte humana que la que fué la tragedia griega.

En este infierno de pasiones contradictorias, de sentimientos sublevados, de lascivia roja, de mentira permanente, de encanallamiento perpetuo, ¿cómo se hizo la historia de América? ¿C6mo la concibieron y la hicieron los cronistas? Los que no estuvieron en el continente nos han dejado una impresión que parece verdadera. Los que conocieron a los hombres tiñeron sus juicios en el rebalse del elogio o en la diatriba de la enemistad. Un humanista milanés, hombre tipo del Renacimiento, andador incansable de cortes, Pedro Mártir de Anglería, amigo de papas, cardenales y reyes, es el primero que, con curiosidad periodística, nos consigna, a modo de albricias, sus datos e impresiones del descubrimiento de América. Espíritu zahorí y diligente, ávida de noticias, en sus Epístolas, en sus Décadas, en el Opus Episto- 
larum y, especialmente, en las Décadas de Orbe Novo, nos traza con la precipitación vehemente del periodista noticiero, los más acentuados rasgos de la epopeya que iba a comenzar para transformarse luego en drama. Conoció a Colón y registr 6 sus papeles. Nos dió una visión bastante comprensiva de la tierra descubierta. Después del Almirante, Pedro Mártir es el segundo poeta en prosa de la magna hazaña. A Colón le arrancó el espectáculo soberbio de la naturaleza del Nuevo Continente sus más emocionados acentos. Era el contraste de dos mundos, la visión primera de lo desconocido, lo que puso en su pluma esa nota de lirismo. Cantó con inspiración saturada de vehemencia, lo que sus ojos maravillados vieron en la selva exuberante, en el río cristalino, en el mar espeso de los sargazos, en las noches voluptuosas y serenas de los trópicos. A Pedro Mártir le iba a llamar la atención la historia natural, los ritos y creencias del indígena, en los cuales se entretiene con cierta curiosidad sensual y lujuriante. Los más remotos vestigios de la antropología americana encuentran en este humanista, que escribía en pésimo castellano, un cultivador entusiasta. Por desgracia, el sabio milanés veía las cosas con el criterio ligero y novedoso del periodista, y a fe que fué un precursor del género. Por muy crasos que sean los errores en que incurriera Pedro Mártir como cosmógrafo que hablaba de latitudes desconocidas; por más defectuosa que sea su descripción de la historia natural americana y de las creencias y supersticiones de los indígenas, pueden y deben disculpársele por las imprecisas fuentes de información de que dispuso. Hay que concederle a su obra un valor permanente, porque aparece inspirada en una ardiente admiración al Almirante de Castilla, cuyos papeles hurgó, cuyas conversaciones sintió, y cuyo retrato moral se desprende nítido de su Opus Epistolarum. Los mismos errores de las Epistolas, provienen de su condición de periodista, y $e l$, sin alterarse, a la pata la llana, como quien así lo dijera, se corrige con naturalidad, con un desenfado que por el incesante afán de perseguir la verdad, lo torna hacia nosotros cariñoso amigo.

A su lado Andrés Bernáldez, cura de los palacios, es otra piedra básica de la primitiva historia americana. No viajó al Nuevo Mundo al igual que Pedro Mártir, ni supo de las tragedias que la colonización ya comenzaba a hacer sentir. Pero tenía un espíritu claro, sagacísimo y la brillantez pintoresca de los antiguos narradores. Recibió sus informaciones de manos de Colón; y a sus viajes, al recuerdo de su vida pobre y misérrima, a sus andanzas desventuradas y a sus proyectos de iluso que sólo cuajan en Santa Fe, le consagro once capítulos en la Historia de los Re- 
yes Católicos, que la crítica reconoce insuperables por el mérito de haber sido escritos a la vista de documentos auténticos, y haber compulsado la tradición oral.

Un frescor suave de evangélica dulzura cruza por las páginas de Andrés Bernáldez y Pedro Mártir. Es que todavía en los cronistas de ese período, el sabor de sangre caliente no irrumpe como signo de conquista. Es necesario llegar a Gonzalo Fernández de Oviedo y Valdés para sentir ese momento. Hombre de una actividad estupenda, de un vigor físico intelectual superior a toda ponderación, de una energía como era la de esos hombres que parecían salidos de las leyendas del Olimpo, doce veces cruź́ el Octeano para venir a América en varios y señalados cargos de la administración y de la guerra, dándose tiempo, en medio de una actividad febrilísima, para escribir aquel monumento de la historiografía moderna que se llama la Historia General y Natural de las Indias, libro magnífico, duro en su factura, crudo en el estilo, sabio en la abundancia de noticias y, sobre todo, espejo en donde quedan representados los caracteres morales, confusos y heterogéneos, de los hombres de la epopeya y del drama de América. Vasto panorama de la obra de España en el Nuevo Mundo, soberbio exponente de la psicología del pueblo conquistador. Nada hay comparable para el historiador moderno que busca la interpretación de una edad, como las páginas de este narrador en quien, a las veces, la pasión nos hace sentir cuan difícil es llegar a establecer el sentido exacto de los actores que presenta y de los sucesos que detalla

Más fuerte por el tono de protesta que ella representa contra la colonización, es la obra de Las Casas, espíritu terco, de ideas fijas y preconcebidas, violento hasta en su papel de apóstol y evangelizador. En su Historia General de las Indias, con más relieve que Oviedo, nos ha dejado una impresión de la psicología turbia de los hijos de Castilla. Pero donde la pluma de este fraile Protector de los Indios toca los arrebatos de la rebelión del alma, es en la Destrucción de las Indias, libro controvertido, negado por la España en su parte sustantiva, pero cierto en sus noticias, no obstante los visos de una exageración que cuadraba a perfección con el carácter soberanamente terco y tenaz del amigo y compañero de Colón.

En esas obras, en las de Oviedo principalmente, y en las de Las Casas en otro orden de cosas, está, por decirlo así, la suma y substancia de la crónica americana de la colonización contada por testigos oculares, por actores de los sucesos, por hombres que al mismo tiempo que hacían la historia la escribian; teniendo 
en menos, en algún menosprecio, no por desidia, sino por tendencia espiritual, el sentido de la relación documental.

El gran Herrera, que nunca estuvo en América, que era literato y escritor de mérito, pero flojo en los afanes de la redacción, legó al mundo la Historia General de los Hechos de los Castellanos, en que la masa de papeles, de informaciones documentales de primera mano, la hace tanto más apreciable cuanto su autor, por pereza o por ajustarse a un método científico que al ser asfi le haría insigne honor, sólo se limitó a ponerlos en buen estilo y a facilitar su lectura mediante una interpretación que la crítica hoy puede aprovechar con éxito singular.

Tales son las fuentes primitivas de la historiografia americana, en las cuales la humanidad aprendió a conocer el fenómeno del descubrimiento, conquista y población del continente. El método, como bien se comprende, apenas tiene sentido en la obra de los cronistas. El espíritu crítico que suele encontrarse en ellos está de acuerdo con las ideas y preocupaciones de la época; el sentido de la independencia del criterio, de la imparcialidad, no podía exigírseles a individuos que al conseguir el logro de la colonización con el esfuerzo de sus poderosas voluntades, asumían después el carácter de jueces, relatando y juzgando los hombres y los hechos.

La verdad es constante como la ola. Y las ondas de las aguas que se suceden de un pequeño círculo a otro más amplio y cada vez más amplio, es como la perenne renovación del ideal que aspira a la perfección eterna. Así, no era raro que de la misma patria hacedera de la empresa sobrehumana de la civilización de un mundo, salieran los primeros aportes para la rectificación del gran arsenal histórico que significó la obra de los cronistas. Esta tarea la inicia un erudito llamado Andrés González Barcia, en un aspecto modesto, pero el más interesante por los expurgos bibliográficos de joyas preciosas que pone a disposición de la crítica. Y es él quien prepara, con la publicación de los Historiadores primitivos de Indias, el campo de la iniciación del período de la historiografía crítica americana.

Pero González Barcia no entendió su papel de bibliógrafo como un simple amador de textos. Algo más culto que la generalidad de los hombres de su época en la península, lector infatigable de las obras americanas hasta entonces publicadas o inéditas hasta el siglo XVIII, su siglo, adicionó los tratados primitivos de los cronistas con notas y referencias de un valor inestimable. Tiene un mérito mayor aun: como bibliógrafo eruditísimo, puso al día la obra madre del fundador de la bibliografía americana, don Antonio León de Pinelo, el famoso 


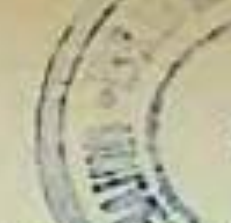

\section{Epitome de la Biblioteca Oriental y Occidental.}

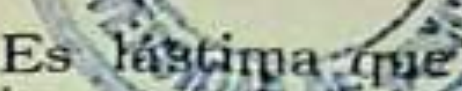
González Barcia citara muchas veces de memoria, pexd lo mis mo había hecho el autor peruano del primer ensayo de una bibliografía de las obras relativas al Nuevo Mundo, algunas de ellas escritas por americanos. Este es el mérito de González Barcia como divulgador de la rama de la ciencia historiográfica que se llama americanista.

Desde ese momento también se opera en la historiografía de América un movimiento tan rigurosamente crítico, tan estrictamente ajustado al método más férreo, que comienza a mirar con desconfianza el valor del testimonio de los libros para entrar al examen cuidadoso y prolijo de la documentación. Formalmente aquí comienza la aplicación del método en la historia americana, método que, mejorándolo, tratarían de llevar a un alto grado de perfección tanto Harrisse como Medina.

El principio universal de la duda, a pesar de la opinión contraria de las autoridades más respetables en la materia, habría de producir en breve los más espléndidos resultados. El nombre de ese innovador radical en el siglo XVIII es el de Juan Bautista Muñoz, el último de los cronistas oficiales de Indias. Muñoz era valenciano, con lo cual queremos decir que el don de la imaginación estaba en él. Pero no tenía una imaginación desordenada, tan sólo apta a las inspiraciones de la poesía; antes por el contrario, la suya vinculábase a los estudios filosoficos, a las grandes y sutiles cuestiones del humanismo. De ahí la solidez de su juicio, su admirable sentido crítico y las excelencias del método que aplicara. El se propuso establecer documentalmente-como habría de hacerlo después Medina-todo el proceso de los orígenes de la dominación española. Ya no bastaban los libros para la certificación de los sucesos; era menester que ellos encontraran su prueba básica, concreta, en los papeles, cartas, oficios, relaciones, sumarios y procesos.

iCalcúlese el inmenso valor que para desentrañar la psicología del hombre de la conquista, significaba entonces y significa en nuestros días un procedimiento semejante! Muñoz procedió movido de un alto espíritu patrio. En esos días las glorias de España, después de la aparición de la obra del inglés Robertson intitulada Historia de América, quedaban maltrechas y vilipendiadas, y es claro que el orgullo de la raza necesitó de una vindicación muy amplia. La ciencia ganó con ella, porque así fué dable que Carlos III abriera de par en par los archivos, y entregara al público el dominio de los tesoros escondidos. Por suerte, Muñoz fué encargado, como cronista de Indias, de la rebusca de los testimonios que el soberano, por intermedio de 
este humanista, iba a presentar para contradecir las afirmaciones de Robertson. En esta peregrinación demoró el valenciano siete años, durante los cuales no dejó rincón de biblioteca y archivo peninsular que no hurgara. Su acopio de documentación, para ilustrar los puntos más obscuros de nuestra historia, fué extenso, variado, concluyente; pero, por desgracia, apenas publicado el primer volumen de la Historia del Nuevo Mundo, obra más bien retórica que erudita, el célebre humanista rindió el ánima, dejando a la posteridad la valiosa herencia de su archivo en el cual han bebido y siguen bebiendo los nuevos historiógrafos.

En el siglo XIX y escriben los cuatro más grandes americanistas de todos los tiempos: Martín Fernández de Navarrete, Alejandro de Humboldt, Henry Harrisse y José Toribio Medina. A ellos se les debe la aplicación definitiva del método científico en la investigación documental, bibliográfica y crítica de nuestra historia. Ellos lo fijaron de una manera cierta. Lo problemático, lo inseguro, lo dudoso, en las manos de estos hombres, encontró las vías más directas de una verificación, y abrieron a la ciencia nuevos e inmensos horizontes. Fernández de Navarrete reconstruý, etapa por etapa, la historia del desarrollo de la geografía del nuevo continente. La náutica de los españoles y su arte de navegar, aparecen expuestos a la luz de una crítica tan recta como segura. La obra en que este marino, gloria de España, vacio su ciencia, es una de las compilaciones más sabias que haya logrado la cultura moderna. Llámase Colección de Viajes y Descubrimientos que hicieron por mar los españoles desde fines del siglo $X V$. Título muy largo y fatigoso, que apenas nos da idea de su notable contenido. De este libro habría de decir el hombre más sabio de su siglo, la primera autoridad de la ciencia, Alejandro de Humboldt, que era chonra de la sabiduría de un pueblo». Tal elogio lo escribía el mismo autor de aquel monumento intitulado Examen crílico de la historia de la Geografía del Nuevo Continente $y$ de los progresos de la Astronomia Náutica de los siglos $X V$ y XVII, el mismo Alejandro de Humboldt, que hubo de servirse en todo y para todos los puntos fundamentales de la obra de Navarrete, como que en ella se encuentra el cimiento y la poderosa argumentación en que se apoya. El gran alemán, que parecía llevar como de frente todos los conocimientos humanos, haciendo servir los unos de ilustración y complemento a los otros, al decir de uno de sus críticos, ensanchó la perspectiva de la historia fijando las causas científicas que preparan el descubrimiento de América, y los pormenores concernientes a la vida y carácter de Colón; estudió los viajes verdaderos o supuestos de Américo Vespucio, y la cro- 
nología de los primitivos descubrimientos de los españoles en el nuevo continente.

No puede hablarse aquí de algunos otros historiadores y eruditos de importancia menor, que si bien muy distinguidos y de alta significación, que no entran en los límites de este ensayo; ni tampoco sería propio citar, siquiera no más fuera de simple referencia, un buen número de historiógrafos locales, que han contribuido con sabios trabajos a la puntualización de algunos de los problemas secundarios de la historiografía del mundo de Colón. Pero hay una figura que, en la segunda mitad del siglo XIX, aparece violenta y desbordante en el campo del americanismo, y que tiene con Medina más de un punto de semejanza en la vocación intelectual y en la rigidez del método científico.

Se habrá entendido que hablamos de Harrisse. Era francés de nacimiento, nacionalizado ciudadano norteamericano, de origen judío por sus padres rusos. Abogado como Medina, bibliógrafo como el sabio chileno, historiador de los viajes de los espanoles, no.tuvo, sin embargo, ni la mansedumbre ni la modestia de nuestro compatriota. Al contrario; en Harrisse, su alto y desmesurado amor propio, su orgullo incontenible y feroz, la certeza de su brillante inteligencia y de su aplastante espíritu razonador de que estaba tan plenamente convencido, le hicieron personaje insoportable en su tiempo; pero nadie podrá negarle los títulos con que le recuerda el americanismo del cual fué príncipe, sin duda, hasta que Medina le arrebatara el cetro en el dominio de sus mismos estudios. A él se debe la Biblioteca Americana Vetustísima, ensayo crítico bibliográfico, preñado de erudición y sana crítica, que abarca desde 1492 hasta 1551 , libro fundamental, pero rehecho de fondo a superficie por Medina.

Con Navarrete, Humboldt y Harrisse se cierra el primer período crítico moderno, por decirlo así, del americanismo en el siglo XIX. Las líneas generales del método quedaban trazadas. Sólo cabía ahora particularizarlo en los accidentes que aquellos hombres de ciencia no pudieron conseguir. Pues bien; a partir de fines del siglo XIX hasta nuestros días, hasta ayer no más en que murió, José Toribio Medina llevó de frente todos, absolutamente todos, los problemas capitales y sustantivos de la historiografía americana. Nacido en 1852 y educado en la tradición de Bello que todavía imperaba pura entre nosotros, la vocación de su espíritu le lleva como por intuición al cultivo de las ciencias naturales. Todavía no se despertaba en él el gusto, el afán de los estudios que habrían de hacer su nombre perdurable y magnífica la fama de sus libros.

Se olvida con frecuencia por los biógrafos y por los críticos de 
Medina esta su primera iniciación intelectual, y es interesante subrayarla porque de ella arranca una parte del valor permanente de su inmensa labor. Medina, al entrar al campo de las ciencias históricas, en la cual habría de ser gran señor y príncipe indiscutible, llevaba de antemano la fijeza de juicio que da el método que él había desenvuelto en las ciencias naturales. Su paso por ellas qued6 señalado por varios descubrimientos novedosos. Una especie encontrada y descrita por Medina lleva su nombre dado por el Doctor Phillippi. Era entonces demasiado joven. Acababa de recibir su título de abogado. Un accidente, dentro de las mismas disciplinas de zob́logo que cultivara, le puso entre las manos a los primeros cronistas chilenos. Buscaba antecedentes entomológicos para sus estudios. Pero en $\mathrm{Me}$ dina habia una sensibilidad virtuosa y casi sentimental por el estudio, y la lectura de los historiadores primitivos despertó en su alma, no como se ha creído el rumbo definitivo de su carrera, sino el deseo de llegar a conocer profundamente la historia del hombre aborigen en el suelo chileno. Se hizo etnólogo y antropólogo. Así, en busca de materiales para descifrar el enigma misterioso $\mathrm{e}$ insondable del habitante nacional, recorren la tierra del país, y acumulando los materiales necesarios para un libro intitulado Los Aborigenes de Chile, que publica mucho después, cuando ya habían aparecido algunos de sus libros históricos.

Ciertos detalles psicologicos en la vida de los grandes hombres suelen explicar con claridad su historia espiritual; y por cierto que en el caso de Medina es preciso buscar algunas de sus cualidades morales e intelectuales en la que fué su ascendencia. Su padre fué un hombre culto, que en momentos de abatimiento y soledad, en plena juventud, anduvo enredado con las musas. Fué un poeta romántico, que cantó con acentos doloridos los sentimientos en boga de su tiempo. Ni buenos ni malos, en sus versos pueden encontrarse reminiscencias de una esperanza de bienestar y de grandeza que acaso nunca llegaron al logro apetecido. como lo imaginaba el poeta. Abogado y más tarde juez de virtudes superiores por la rectitud y hon radez que demostrara en la carrera de magistrado, el natural de su temperamento aveníase mal con las funciones que le deparó la vida. Amigo de la lectura, de la charla, de la vida social, el sino del destino no pareció sino contrariarle las que fueron sus mejores condiciones de hombre jovial y de mundo. Cuando todavía no frisaba en los cuarenta de Mañara, la parálisis entorpeció sus miembros y qued6 reducido a la impotencia física. Esa inteligencia viva, brillante, que denotaba su origen andaluz, vivió una exis- 
tencia de martirio, que había de prolongarse por largos años hasta que la muerte cortara el aliento del infeliz inválido.

La tenacidad de Medina para el trabajo, la energía del carácter, la voluntad de acero nunca reducida, no fueron condiciones heredadas de su padre. A él le debió la inteligencia, la extraordinaria memoria sin igual de que estaba dotado, la reflexión honda y certera, la imaginación chispeante y ese don de mundo que manaba de su aparente áspera corteza. Esas otras condiciones provenían de su madre. Su abuelo materno era de ascendencia vasca. Fué uno de los más ricos mineros del norte en los tiempos en que Copiapó era como una montaña de plata. La tenacidad del abuelo para buscar en las rugosas quebradas de las cordilleras las vetas del metal soñado, la inquebrantable energía para no ceder ante los obstáculos y conseguir el fin deseado ino son, acaso, las mismas que Medina nos descubre como investigador, a quien ni siquiera arredra la pesadumbre física de una tarea que, al concebirla, parecía propia de una legion de hombres? A mí me decía un día como queriendo impulsarme al camino oscuro, pero noble, que él había recorrido: $\star$ No debes dejar pasar una mañana sin hacer un apunte, una tarde sin escribir una página, una noche sin leer una líneas. He ahí su sistema. Su madre, en otro sentido, había hecho otro tanto, cuando los azares de la vida la obligaron a convertirse en el timón de su hogar desgraciado por la invalidez del esposo.

Un viaje al Perú, como Secretario de la Legación de Chile, puso a Medina en el camino de las investigaciones propiamente históricas. En este instante decisivo de su vida, se inicia su vocación. En una carta escrita a su padre le dice a este respecto:

<Me he visto obligado a no poder continuar en esta ciudad ( $\mathrm{Li}$ ma), mis estudios de las ciencias naturales y de la antropología, por lo cual, para matar el tiempo, me he dedicado a recorrer los archivos y las bibliotecas para ver manera de encontrar algo útil para Chile, y también porque creo que en ellos puedo hallar antecedentes que sirvan a mis puntos de vista sobre los primeros habitantes del país». Es decir, la historia para Medina hasta entonces, es como una ciencia auxiliar que sirve para corroborar sus hipótesis de carácter antropológico. ¡Curiosa situación la suya! Posiblemente el campo en que espigaba no le fué favorable a sus pretensiones en la amplitud que él lo deseaba, y por ello se engolfo en la compulsa estricta de la historiografía.

Lima era entonces el centro de un movimiento intelectual interesante. Medina convivió en los cenáculos literarios que juntaban los nombres de Ricardo Palma, Manuel de Odriozola, González Vigil y tantos otros. Y allí inicia, en la ciudad de los 
virreyes, sus primeras colaboraciones en El Correo del Perí. ¿Qué escribe? Orienta sus estudios hacia la historia literaria; se vislumbran los capítulos primeros de ese gran libro que todavía queda en pie, que habría de llamarse Historia de la Literatura Colonial de Chile. Por esos trabajos vemos cuán remota es su devoción a Ercilla. En los primeros artículos consagrados al poeta vizcaíno, está como la síntesis de su obra maestra de la mayor edad: el estudio monumental de La Araucana y de la vida del cantor de las guerras de Arauco.

El orfebre ama sobre todas las cosas el oficio que cultiva. La razón de su vida parece unirse a él. Es el amor puro que no agosta ni seca la virtud de los cinceles, el que mueve su alma en un afán renovado de belleza. En Medina, descubierta la pasión, el vuelo se torna incontenible. Necesita otro escenario, otro mundo. Y corre a Estados Unidos, Francia, Londres, Alemania y España. Sevilla es como la consagración de su ideal. Sabe que en sus calles morunas, estrechas, rumorosas de alegría y pintadas de color, más allá del Alcázar, cerca de la Giralda, donde pasan mujeres de ojazos negros entonando una canción, envueltas en mantones de Manila con gamas de perlas y rubies, hay un lugar de silencio, de paz y recogimiento donde anidan los siglos de la historia sus leyendas, y en cuyos fríos anaqueles ha quedado sepultada la vida palpitante de lo que fué lo heroico, grande y sublime. ¡Oh! qué magnífica impresión recibió el joven, todavía adolescente, al transponer los umbrales centenarios del Archivo de Indias. Sobrecogido, tímido, tembloroso, la vieja casona mandada construir por el rey de reyes, Felipe II, iba a entregarle generosa los secretos de ese mundo muerto que fué la historia de América. Las horas son escasas para el estudioso; las vigilias lo encuentran sin que se sucedan las vísperas; las tardes declinan con cielos de arreboles, y el muchacho está siempre inclinado sobre un viejo, amarillento, desgajado pergamino.

Fructuosa estancia la suya. A la vuelta al terruño, hartas las maletas de papeles y de libros, henchida la cabeza de proyectos, entrega su primera y definitiva obra que es asi como su consagración: La Historia de la Literatura Colonial de Chile, libro de juventud, premiado por esta Universidad. Revaluar el pensamiento de los escritores del período de la dominación española, desde Ercilla hasta Lacunza, desde Oña a Barrenechea de Alviz, desde Núñez de Pineda hasta Molina, he ahí lo que significa esa obra de alta crítica literaria, de investigación ordenada y circunspecta, de revisión de juicios y opiniones.

Quiere la ciencia aunar siempre sus resultados, y el hombre que la cultiva solo ve en ella su continuidad eterna. La prepa- 
ración de la Historia de la Literatura Colonial de Chile había significado para Medina una labor previa de investigación bibliográfica, de compulsa de textos, de crítica de ediciones, de desciframiento de problemas que aparecían confusos y mal estudiados. El bibliografo nació de aquí. Persuadido de que no era posible establecer la historia literaria de América sin que antes se hiciera el recuento, por así decirlo, de la producción intelectual del continente, a este tiempo pertenece su plan de historiar el curso de las visicitudes de la imprenta en el Nuevo Mundo.

Es evidente que el año 1886 marca en la vida de Medina el punto medio exacto de una nueva orientación en su carrera de histori6grafo. Hasta entonces su obra aparece exclusivamente consagrada a ilustrar la historia de su patria. El deseo de Medina, su aspiración más vehemente, lo que podría decirse era su ideal, no era otra cosa que la de escribir una historia general de Chile durante el coloniaje. Para conseguir ese fin comenzó a editar la Colección de Documentos Inéditos para la Historia de Chile, sobre la cual no tengo para qué detenerme en probar su valor, ni en exaltar la fidelidad paleográfica con que han sido publicadas sus piezas, puesto que Thayer Ojeda y Amunátegui Solar han pronunciado juicios severamente justos $y$ exactos. En la Colección de Historiadores de Chile reinició la publicación de los antiguos cronistas, acompañando a los textos sabiamente depurados y anotados, prolijas biografías de sus autores. Sin embargo, y sin dejar ni por un momento de mano sus labores de la Historia de Chile, Medina abarca repentinamente toda la historia de América, entiéndase bien, la historia general del continente y la local de cada uno de sus países. Esta violenta evolución de Medina en el cambio de sus estudios, es la obra de una mujer. Clotilde de Veaux inspiró a Augusto Comte para escribir la Sociología, sacándolo de la especulación filosófica de ideas $\sin$ mayor originalidad en su tiempo. Mercedes Ibáñez de Medina, la esposa del historiador, es quien abre al erudito un horizonte que, por modestia, nunca hasta entonces se atrevió a explorar.

He señalado, precisamente, el año de 1886 como decisivo en este aspecto de la carrera del escritor, porque desde entonces, a partir de su matrimonio, se ve el propósito de dejar la historia de la tierra hogareña para penetrar en cuestiones de interés universal más amplio y permanente.

Las mujeres chilenas del tiempo de la señora de Medina, no valían mucho por su cultura ni por la perspicacia de la inteligencia. Se sentían aptas para ser fieles y cariñosas esposas, tiernas y sacrificadas madres en esta tierra que fué hogar de 
purísimas virtudes. Una mujer chilena en la segunda mitad del siglo XIX, vivía intelectualmente divorciada del esposo. No había para ella más que la casa, la familia y la iglesia. La señora de Medina, educada en otro ambiente, fuera de las fronteras, es desde ese momento la heroína anónima de los trabajos del historiador, la inspiradora discreta y la colaboradora afectuosa de su obra. Hay algo de extraordinario en esta mujer que ahogo su feminidad en el cultivo de los libros para seguir las huellas del esposo. Aquí debe recordársele con cariño y con respeto, porque acrecentó la gloria de su patria primero, y después la del grande hombre. A ella le pertenece, pues, una parte de ese nimbo de luz.

Hemos querido traer estos datos para explicar siquiera la trayectoria moral de la obra de Medina. Ahora que estamos en ella, debemos repetir la interrogación que nos hicimos: ¿Cómo entendieron la historia de América los hombres que iniciaron la razón crítica de ésta? Medina comprendió que había de abarcarla en su totalidad. Ya no eran las grandes cuestiones las que debían ser dilucidadas. Sabía que si allí había puntos obscuros que él mismo corrigi6, era preciso, sobre todo, llegar a revisar el método de Muñoz y de Harrisse.

Medina corrigió a Navarrete y Harrisse. Esas obras que parecían inamovibles en la historia de la geografía, el sabio chileno las adiciono y las revolucionó con sus libros sobre Caboto, del cual dijera Harrisse que había superado el suyo. Orellana, Vasco Núñez de Balboa, Magallanes, Juan Díaz de Solís, Pancaldo, Juan Fernández, Diego García, Gonzalo de Acosta, Esteban Gómez, encuentran en este erudito al historiador feliz y afortunado de los grandes y poéticos náuticos españoles.

Apenas si puede hablarse en una disertación como ésta, del que fué espejo maravilloso de bibliógrafos. Harrisse había creído agotar el tema en su ya citada Biblioteca Americana Vetustísima, y parecía difícil seguirlo siquiera o completarlo. Medina iba a agregar a su Biblioteca Hispano Americana, en una obra nueva por su factura, 1,040 títulos más.

Todo adquiere en Medina proporciones gigantescas. Al enumerar su labor, el sustantivo y el adverbio ya no encuentran sentido de individualidad. $Y$, sin embargo, hay algo más que decir: la inquisición. La inquisición es un fenómeno social de la época, muy propio y característico del tiempo español. Para un liberal de escuela, el estudio de esos procesos ¿no ponía el aguijón de una campaña? Pues nada; la honradez del historiógrafo, sin sentir la pasión sectaria de una época ultramontana en que se pedía a gritos la condenación de la iglesia, encuentra 
en Medina un expositor que sirve a una y otra tendencia. He ahí su honradez espiritual. Al revisar la historia de América, y al expurgarla, encontró todavía que para completar el cuadro le faltaba algo: el estudio de las monedas y medallas. Hoy que la historia se orienta hacia un sentido económico, Medina será el que explique en esos sus libros, cuál ha sido el valor del oro, y las enseñanzas amargas que se desprenden de su conquista.

No se puede hablar de este hombre sin esquematizar su obra en una clasificación que revele de golpe su importancia. Quien desee estudiarla tendrá que llegar a un esquema de su labor de erudito que es, como decía el director del Museo Británico, Garnett, compendio y sintesis de la vida entera de todo un continente. Esa tarea ha sido ya realizada con muy diverso criterio. La acometió primero Armando Donoso en un ensayo crítico sobre la obra del polígrafo chileno, publicada en el libro intitulado La otra América. Allí clasifica la producción de Medina en ocho categorías de fuentes, por decirlo así, que enumera en esta forma: PUBLICACIONES DE ORDEN CIENTÍfFICO: entomológico, folklórico, arqueológico, etnográfico, docente, cartográfico, como los artículos sobre los insectos enemigos en Chile, el mito popular El Piuchén, Los restos indígenas de Pichelemu, y los libros Los aborígenes de Chile, La instrucción pública en Chile, Ensayos acerca de una mapoteca chilena. PuBLICACIONES DE CARÁCTER HISTÓRICO-DOCUMENTAL: relativas a la América española y a las islas Filipinas, como son todas las que se refieren al Tribunal del Santo Oficio en Chile, Lima, México, etc. Publicaciones de CARÁcter bibliográfico AmeriCANO: cuales las siguientes: Biblioteca hispanoamericqna, Biblioteca hispanochilena, y todos los volúmenes relativos a la historia y la bibliografía de la imprenta en la América Española.-PuBLrCACIONES DE DOCUMENTOS $Y$ REIMPRESIONES HISTÓRICAS $Y$ LITERARIAS: tales la Colección de documentos inéditos y la Colección de historiadores, cuyos once primeros volúmenes fueron publicados por Barros Arana, Amunátegui y Montt; las ediciones de Pedro de Oña, la Doctrina cristiana en lengua guatemalteca, La Araucana, etc.-PUBlicaciones DE CARÁCTER HISTÓRICOGEOGRÁfrco: Así, los libros Viajes de Diego García de Moguer al Río de la Plata, El veneciano Sebastián Caboto al servicio de España, El descubrimiento del Océano Pacifico, Vasco Núñez de Balboa y sus compañeros, Descubrimiento del Río de las Amazonas, Hernando de Magallanes.-PUBLICACIONEs soBRE NuMISMÁtica: Los estudios sobre numismática argentina, medallas coloniales hispanoamericanas; los libros Medallas de proclamaciones y juras, las Monedas obsidionales, Monedas coloniales 
de Chile, Medallas del Almirante Vernon.-Publicaciones DE ERUDICIÓN LITERARIA: Historia de la Literatura colonial de Chile, los tres volumenes consagrados a la vida de Ercilla y las ilustraciones de La Araucana, El disfrazado autor del Quijote, impreso en Tarragona, la Novela de la tia Fingida, la Literatura Femenina en Chile.-PUBlicaciones RELATIVAS A LA HISTORIA DE CHIle: Tomando en cuenta sus numerosos prólogos, anotaciones, estudios, traducciones de muchos libros que tratan sobre Chile, es preciso recordar sus libros Cosas de la Colonia, Diccionario biográfico colonial de Chile y los Jesuítas expulsos de América en 1767, abundantes en curiosas noticias del país.

Tal es la clasificación de la vasta obra de Medina realizada por Donoso. Como toda clasificación es arbitraria, por ser una forma de categoría del espíritu. La de Omer Emeth (Emilio Vaīsse), publicada en 1924 en el homenaje que la Sociedad Chilena de Historia y Geografía tributo a Medina al enterar cincuenta años de labor literaria, es más bien un estudio de los materiales que sirvieron al escritor para levantar el gigantesco edificio de su construcción intelectual. La que nosotros damos a continuacion no tiene otro objeto que presentar clasificada, con distinto criterio, la labor del polígrafo. No la creemos ni mejor ni peor que la de Donoso, ni la reputamos tampoco definitiva. Puede considerársela, en todo caso, como un ensayo más completo que las que le han precedido. Héla aquí (1):

1. Critica Literaria: María, apuntes para tico (1 y 288). El amor en la Araucana (6).

un juicio críErcilla juzgado por la Araucana (10). La Crónica de 1810, por-don Miguel Luis Amunátegui (108). Una nueva edición francesa de La Araucana (117). Un libro raro: El temblor de Lima (192). Dos Comedias Famosas y un Auto Sacramental, basados principalmente en La Araucana de Ercilla, anotadas y precedidas de un Prologo sobre la Historia de América como fuente del teatro antiguo español (238 y 254). El disfrazado autor del \&Quijote? impreso en Tarragona fué Fray Alonso Fernández (260). El Lauso de Galatea de Cervantes es Ercilla (266). Novela de la

(1) El número entre paréntesis que lleva cada título corresponde al que se encuentra en las dos siguientes bibliografías de Medina: Catálogo de las publicaciones de D. José Toribio Medina (1873-1914) por Viclor M. Chiappa. Continuado hasta el dfa y sestuido de una bio-bibliograffa por Guillermo Feliú Crus, Santiago, 1924. Comprende este inventario desde el N. ${ }^{\circ} 1$ al 306.

La segunda de estas publicaciones lleva por título: Bibliografía de Don José Toribio Medina. Notas criticas, pnr Guillermo Feliú Cruz. Buenos Aires, 1931. - Comprende desde el N. 308 al 408 . Hemos creído de interés señalar los números para quien desee mayores informaciones bibliográficas: 
Tía Fingida. Con anotaciones a su texto y un estudio crítico acerca de quien fué su autor (275). Escritores hispanoamericanos celebrados por Lope de Vega en el Laurel de Apolo (285). Cantos XVIII y XIX de Armas Antárticas, poema de D. Juan de Miramontes y Zuazola, que reimprime con un breve prólogo y notas críticas e historicas (307). Amarilis y un viejo problema literario en la poesía Americana (312). El Licenciado Pedro de Oña. Estudio biográfico crítico. Por Enrique Matta Vial. Con un prólogo (315). Una traducción de Petrarca hecha en América en el Siglo XVI (320). Aurelio Díaz Meza: Leyendas y Episodios Chilenos. Crónicas de la Conquista. Tomo primero. Prologo de D. J. T. Medina (323, 372 y 380). Viaje del Parnaso compuesto por Miguel de Cervantes Saavedra. Edición crítica anotada por J. T. Medina (328-329). Las mujeres de «La Araucana» de Ercilla (368-369). La Araucana. Ilustraciones: estudios críticos sobre Ercilla.

2. Historia Natural: Los insectos enemigos en Chile (2 y 287). El Piuchén (3). Motivos para la fundación de una Sociedad Entomológica chilena (4).

3. Traducciones: a) Simples; b) Con prólogos, adiciones y notas.

a) H. W. Longfellow: Evangelina. Cuento de la Arcadia (5 y 101). Diario de un joven norteamericano detenido en Chile durante el periodo revolucionario de 1817 a 1819 . Traducido del inglés (92). Dos obras de Viajeros Norteamericanos traducidas al castellano (259). Santiago y Valparaíso ahora un siglo. Relato de un viajero ingles (291 y 292).

b) Memorias de un oficial de marina inglés al servicio de Chile, durante los años de 1821-1829 (295). Insurrección en Magallanes. Relación del apresamiento y escapada del Capitán Chas. H. Brown, del poder de los penados chilenos. Traducción y anotaciones (296).

\section{Biografias: a) Colectivas y b) Individuales.}

a) Los Errázuriz. Notas biográficas y documentos para la historia de esta familia en Chile durante la colonia (90). Diccionario biográfico colonial de Chile (165). Noticias biobibliográficas de los Jesuítas expulsos de América en 1767 (235). Cuatro muertos ilustres (249 y 324). Escritores hispanoamericanos celebrados por Lope de Vega en el Laurel de Apolo (285). Can- 
tos panegíricos a los Invictos Héroes, Maestres de Campo, Abuelos, Bisabuelos y Padre del Muy Insigne Doctor don Tomás Pizarro Cajal. Tercera edición ilustrada con notas biográficas, por J. T. Medina (348). Los estudiantes forasteros en la Real Universidad de San Felipe de Santiago de Chile (370). La Araucana. Ilustraciones. Los compañeros de Ercilla.

b) Fray Miguel de Aguirre (6). Fernando Alvarez de Toledo (7). El Capitán de fragata, Arturo Prat. Estudio sobre su vida, por Ramón Guerrero Vergara, antiguo teniente de Marina; y... (15). Francisco de Aguirre en Tucumán: Un documento interesante para la Historia Argentina (69) Juan Núñez de Prado y Francisco de Villagra en la ciudad del Barco: Un documento interesante para la Historia Argentina (74). Juan Díaz de Solís. Estudio historico (75). Juan Díaz de Solís. Estudio histórico. (Documentos y bibliografía) (76). D. José Mariano Beristain de Souza. Estudio bio-bibliográfico (83). Santo Toribio de Mogrovejo, Arzobispo de Lima (capítulo incompleto de un libro inédito) (169). Un precursor chileno de la revolución de la Independencia de América (205 y 206). Fray Diego de Landa inquisidor de los indios de Yucatán (213). El Proceso de don Carlos de Mendoza (218). El viaje de Ercilla al Estrecho de Magallanes (219). Biografía del general de brigada don José Rondizzoni (223). El Vicealmirante, don Patricio Lynch (229). Juan Gómez de Almagro, el que aprobó eLa Araucanas. Esbozo biográfico (246). El Primer poema que trata del descubrimiento del Nuevo Mundo. Reimpresión de la parte correspondiente del Carlo Famoso de don Luis Zapata, con breve prólogo biográfico y cien compendiosas notas críticas-históricas (247). El Testamento de Francisco Caro de Torres (256). Bartolomé Ruiz de Andrade, primer piloto del Mar del Sur. Estudio historico (276). El Preceptor de Ercilla. Ilustraciones históricas de «La Araucana». Nota bio-bibliográfica de Juan Cristóbal Calvete de la Estrella (277 y 325). Noticia biográfica sobre Fray Antonio Sors y su Historia del Reino de Chile situado en la América Meridional (284). Don Juan Francisco de Sobrecasas, autor de la Relación de la isla de Juan Fernández (293). Apuntes para una Biografía de don Antonio Quintanilla (313). Vida de Sor Ana Guerra de Jesús (337). D. Manuel Antonio Talavera primer cronista de la Revoluçión de la Independencia de Chile. Esbozo biográfico (350351). La Expedición de Corso del Comodoro Guillermo Brown, en aguas del Pacífico. Octubre de 1815-Junio de 1816 (363).

\section{Folklore: Los Araucanos y la Astrología (8). Los Ro-}


mances basados en La Araucana. Con su texto y anotaciones y un estudio de los que se conocen sobre la América del Sur anteriores a la publicación de la Primera Parte de aquel Poema (264). Paremiología Chilena. Discurso leído por D. Ramón A. Laval en su incorporación el 30 de Noviembre de 1923, y contestación de D. José Toribio Medina (308-309).

6. Recopilaciones Documentales: Memorias del Reino de Chile y de don Francisco Meneses. Escribíalas el P. Fray Juan de Jesús María. Publicadas con una introducción biográfica y algunas notas. (9). Las guerras de Chile. Poema histórico por el Sargento Mayor, don Juan de Mendoza Monteagudo. Publicado con una introducción, notas e ilustraciones (28). Histórica relación del Reino de Chile y de las misiones y ministerios que ejercita en él la Compañía de Jesús, por Alonso Ovalle. Reimpresa con una introducción biográfica y algunas notas (30-31). Colección de documentos inéditos para la historia de Chile desde el viaje de Magallanes hasta la batalla de Maipo, $1518-1818(32,39,40,41,64,65,71,72,73,77,78,79,95,96,98$, $103,104,105,118,119,120,122,123,125,126,127,135,136$ y 139). Colección de historiadores de Chile y de documentos relativos a la historia nacional. Tomo XII. Histórica relación del reino de Chile por el jesuíta Alonso de Ovalle. Con una introducción biográfica y notas (34 y 35). Colección de historiadores de Chile y de documentos relativos a la historia nacional. Tomo XIV. Historia geográfica, natural y civil del reino de Chile, por el jesuita Felipe Gómez de Vidaurre. Con una introducción biográfica y notas (36 y 37). Colección de historiadores de Chile y de documentos relativos a la historia nacional. Tomo XVI. Desengaño y reparo de la guerra de Chile, por Alonso González de Nájera. Con una introducción biográfica (38). Desengaño y reparo de la guerra del reino de Chile. Por el Maestre de Campo, Alonso González de Najera. Publicado con una introducción biográfica (43). (Tirada especial). Historia geográfica, natural y civil del reino de Chile, por Felipe Gomez de Vidaurre. Publicada con una introducción biográfica y notas ( 44 y 45 ). Descubrimiento del Río de las Amazonas según la relación hasta ahora inédita de Fray Gaspar de Carvajal con otros documentos referentes a Francisco de Orellana y sus compañeros. Publicada con una introducción histórica y algunas ilustraciones (60). Una expedición española a la tierra de los Bacallaos en 1541 (70). Relación diaria del viaje de Jacobo Le Maire y de Guillermo Cornelio Schouten en que descubrieron nuevo estrecho y pasaje del Mar del Norte al Mar del Sur, a la parte austral 
del Estrecho de Magallanes. Reimpresa con una nota-bibliográfica (82). Colección de historiadores de Chile y de documentos relativos a la historia nacional. Tomo XVII. Actas del Cabildo de Santiago. Tomo II. Con un prólogo $(88,99,110$, $111,128,129,140,157,158,166,167,168,180,181,183,191$. $195,208,214,216,222,239$, en lo relativo a las actas del Cabildo). Colección de historiadores de Chile y de documentos relativos a la historia nacional. Tomo XXIII. Historia de Chile, por don José Pérez García. Con un prólogo (112 y 113). Historia natural militar, civil y sagrada del Reino de Chile en su descubrimiento, conquista, gobierno, población, predicación evangélica, erección de catedrales y pacificación. Su autor, don José Pérez García. Con una noticia biográfica del autor (115 y 116). Colección de historiadores de Chile y de documentos relativos a la Historia Nacional. Tomo XXVI. Historia de Chile, por el P. Miguel de Olivares. Compendio de la Historia de Chile por don Juan Ignacio Molina (130). Colección de Historiadores de Chile y de documentos relativos a la Historia Nacional. Tomo XXVII. Relaciones de Chile, sacadas de los antiguos cronistas de Indias y otros autores (131). Colección de Historiadores de Chile y de documentos relativos a la Historia Nacional. Tomo XXIX. Relaciones de Chile, sacadas de los antiguos cronistas de Indias y otros autores (141). Actas del Cabildo de Santiago durante el período llamado de la Patria Vieja (18101814), publicadas con ocasión de la celebración del primer centenario de la independencia de Chile (196). Colección de Historiadores de Chile y de documentos relativos a la Historia Nacional. Tomo XLV. Los Holandeses en Chile (303). Nicolao de Albenino. Verdadera relación de lo sucedido en los Reinos e provincias del Perú desde la ida a ellos del Virrey Blasco Núñes Vela, hasta el desbarato y muerte de Gonçalo Picarro. Reproducción facsímil con una introducción de José Toribio Medina (385). Documentos de Ercilla (La Araucana).

\section{7.-Historia.-a) Social.-b) De la cultura.-c) Literaria.- d) De la Geografía.-e) Crítica histórica.}

a) Los Morenos y los Briceños. Un pleito de frailes en 1700 (11). Historia del Tribunal del Santo Oficio de la Inquisición de Lima (1569-1820) (23-24). Cosas de la Colonia. Apuntes para la crónica del siglo XVIII en Chile (42 y 194), Historia del Tribunal del Santo Oficio de la Inquisición en Chile (50 y 51). El Tribunal del Santo Oficio de la Inquisición en las Islas Filipinas (100. Historia del Tribunal del Santo Oficio de la Inquisición en Car- 
tagena de las Indias (102). El Tribunal del Santo Oficio de la Inquisición en la Provincia del Plata (106). Historia del Santo Oficio de la Inquisición en México (163). La primitiva inquisicion americana (226).

b) La Instrucción pública en Chile desde sus orígenes hasta la fundación de la Universidad de San Felipe (160 y 161). Introducción de la Imprenta en América. Carta que al señor D. José Gestoso y Pérez dirige J. T. Medina (189). La cultura intelectual en Chile durante el período colonial (193). Las matemáticas en la Universidad de San Felipe (357). Historia de la Real Universidad de San Felipe de Santiago de Chile. (364365). La Medicina y los Médicos en la Real Universidad de San Felipe (366-367).

c) Historia de la literatura colonial de Chile (12-14). El positivismo en Chile (114). La literatura femenina en Chile (294).

d) Los viajes de Diego García de Moguer al Río de la Plata. Estudio histórico (173). El portugués Gonzalo de Acosta al servicio de España. Estudio histórico (174). El portugués Esteban Gómez al servicio de España. Estudio histórico (175). Algunas noticias de León Pancaldo y de su tentativa para ir desde Cádiz al Perú por el estrecho de Magallanes en los años de 1537-1538. Estudio histórico (176). El veneciano Sebastián Caboto al servicio de España y especialmente de su proyectado viaje a las Molucas por el Estrecho de Magallanes y al reconocimiento de la costa del Continente hasta la gobernación de Pedrarias (177 y 178). El descubrimiento de Chile por los frisios en el siglo XI (187). El descubrimiento del Océano Pacífico. Vasco Núñez de Balboa, (215 y 224). El piloto Juan Fernández descubridor de las islas que llevan su nombre, y Juan Juffré armador de la expedición que hizo en busca de otras en el Mar del Sur. Estudio histórico (263). El descubrimiento del Océano Pacífico. Fernando de Magallanes, y sus compañeros (280 y 281). Cartografía Hispano-Colonial de Chile. Texto. Con noticias historicas (317). Cartografía Hispano-Colonial de Chile. Atlas. 1924 (318).

e) El Acta del Cabildo abierto del 18 de Septiembre de 1810 (202 y 391). Carta a don Enrique Matta Vial sobre la Sociedad Chilena de Historia y Geografía. (207). Sobre el valor histórico del cuadro \&Descubrimiento de Chile del señor Pedro Subercaseaux (221). El Acta del Cabildo abierto del 18 de Septiembre de 1810 (234). Sobre el retrato de Diego de Almagro (236). Cervantes en Portugal (338) Escritores Americanos celebrados por Cervantes en el Canto de Calíope (340). Catálogo de la Colección de Manuscritos relativos a la Historia 
de América. Formada por Joaquín García Icazbalceta. Anotado y adicionado por Federico Gómez Orozco. (349). Don García Hurtado de Mendoza a través de la Historia y de la Leyenda (336 y 362). Cómo se llamaron los padres de don Juan Ignacio Molina (375-376). Los que firmaron el Acta del Cabildo Abierto del 18 de Septiembre de 1810 (377). La colección de manuscritos americanos de don Benjamín Vicuña Mackenna (387). El Acta del Cabildo Abierto del 18 de Septiembre de 1810 (389). El Escudo de Armas de la Ciudad de Santiago de Chile (390).

8.- Geografía y Cartografia: Geografía antigua de Chile (16). Ensayo acerca de una Mapoteca chilena o sea de una colección de los títulos de los mapas, planos y vistas relativas a Chile arreglados cronológicamente. Con una introducción histórica acerca de la geografía y cartografía del país (46). Catálogo de la colección de mapas, planos y vistas relativas a Chile de la Biblioteca de J. T. Medina (47). Descripción de las Indias Occidentales por Martín Fernández de Enciso. Sacada de la Suma de Geografía de este autor y reimpresa con un prólogo bibliográfico (81). Relación diaria del viaje de Jacobo Le Maire y de Guillermo Cornelio Schouten en que descubrieron nuevo estrecho y pasaje del Mar del Norte al Mar del Sur, a la parte austral del Estrecho de Magallanes. Reimpresa con una nota bibliográfica (82). Primer viaje de exploración a la isla de Tenqueguén. Diario y derrotero de don Manuel Brizuela, que se imprime ahora por primera vez, con una sumaria noticia de los antecedentes que lo motivaron (250). Geografía antigua de Chile. Nomenclatura de nombres geográficos indígenas de Chile (286).

9.-Etnología, antropología y etnografía.-Chile. Sus aborígenes origen de su nombre (17). Los aborígenes de Chile (20). Los Conchales de las Cruces. Nuevos materiales para el estudio del hombre prehistórico en Chile (89). La momia de Chuquicamata (133 y 268). Los restos indigenas de Pichilemu (172). Una lechuza simbólica, Contribución al estudio de los aborigenes de Chile (282). Algunas piezas notables del rescate, de Atahualpa (346). ¿Para qué pueden haber servido las piedras de horadación inconclusa? (360).

10.-Viajes y relaciones de viajeros.-Una excursión a Tarapacá (18). Visita a los Juzgados de Tarapacá (19 y 227). Una visita al Convento de La Rábida (57). Cartas escritas durante una residencia de tres años en Chile, en las que se cuen- 
tan los hechos más culminantes de las luchas de la revolución en aquel país; con un interesante relato de la pérdida de una nave y de un bergantín de guerra chilenos a consecuencia de un motín, y del arresto y penalidades que sufrieron durante seis meses en las casamatas del Callao varios ciudadanos de los Estados Unidos. Por Samuel Johnston, que estuvo al servicio de los patriotas. Traducidas del inglés (253). Santiago y Valparaíso ahora un siglo. Relato de un viajero inglés. (291). Santiago y Valparaíso ahora un siglo. (Relato de un viajero inglés) (292). Relación del Viaje de Hendrick Brouwer a Valdivia en 1643. Versión castellana y prólogo (311). Relación de un Viaje a Chile en 1698 desde Cádiz, por Mar y por Tierra, escrita en italiano por el P. Antonio María Fanelli, de la Compañía de Jesús, Versión castellana de Elvira Zolezzi, precedida de una noticia bio-bibliográfica (378).

11. - Bibliografía e historia de la Imprenta en América y Oceanía.-Indice de los documentos existentes en el Archivo del Ministerio de lo Interior (21). Biblioteca Americana. Catálogo breve de mi colección de libros relativos a la América latina con un ensayo de bibliografía de Chile durante el período colónial (25). Catálogo de una pequeña colección de libros antiguos sobre la América Española (26). Ediciones de La Araucana (29). Ensayo acerca de una mapoteca chilena o sea de una colección de los títulos de los mapas, planos y vistas relativos a Chile arreglados cronológicamente. Con una introducción histórica acerca de la geografía y cartografía del país (46). Catálogo de la colección de mapas planos y vistas relativos a Chile de la Biblioteca de J. T. Medina (47). La Imprenta en Lima (Epítome) (49). La Imprenta en América. Virreinato del Río de la Plata (Epítome) (52). Bibliografía de La Imprenta en Santiago de Chile desde sus orígenes hasta Febrero de 1817 (53). Historia y bibliografía de la Imprenta en el antiguo Virreinato del Río de la Plata (55). Ensayo de una bibliografía de las obras de don José Miguel Carrera (56). La Ímprenta en México (Epítome) (58). Catálogo de libros españoles, cuya descripción bibliográfica solicita José Toribio Medina (59). Nota bibliográfica sobre un libro impreso en Macao en 1590 (61). El primer peri6dico publicado en Filipinas y sus orígenes (63). Brevísimo epítome de la Imprenta en Manila (1593-1810) (67). La Imprenta en Manila desde sus origenes hasta 1810 (68). Biblioteca hispanoamericana septentrional o Catálogo y noticia de los literatos que o nacidos o educados o florecientes en la América Septentrional han dado a luz algún escrito o lo han preparado para la 
prensa. La escribía el Dr. José Mariano Beristain de Souza. Comprende los anónimos que dejó escritos el autor, las adiciones del Dr. Osores y otras añadidas posteriormente por las personas que se expresan. José Toribio Medina publícalo ahora con una introducción bio-bibliográfica (84). Bibliografía de la Lengua Araucana (85). Bibliografía española de las Islas Filipinas (1523-1820) (86). Biblioteca Hispano-Chilena (1523-1817). (87, 91 y 93). Biblioteca Hispano-Americana (1493-1810) (94-109121-132-138-142-170). La Imprenta en la Habana (1707-1810). Notas bibliográficas (143). La Imprenta en Cartagena de las Indias (1809-1820). Notas bibliográficas (144). Notas bibliográficas referentes a las primeras producciones de la Imprenta en algunas ciudades de la América española (Ambato, Angostura, Curazao, Guayaquil, Maracaibo, Nueva Orleans, Nueva Valencia, Panamá, Popayán, Puerto España, Puerto Rico, Querétaro, Santa Marta, Santiago de Cuba, Santo Domingo, Tunja y otros lugares). (1754-1823) (145). La Imprenta en Veracruz (1794-1821). Notas bibliográficas (146). La Imprenta en Mérida de Yucatán (1813-1821). Notas bibliográficas (147). La Imprenta en Oaxaca (1720-1820). Notas bibliográficas (148). La Imprenta en Caracas (1808-1821). Notas bibliográficas (149). La Imprenta en Bogotá (1739-1821). Notas bibliográficas (150). La Imprenta en Quito (1760-1818). Notas bibliográficas (151). La Imprenta en Arequipa, El Cuzco, Trujillo y otros pueblos del Perú durante las campañas de la Independencia (1820-1825). Notas bibliográficas (152). La Imprenta en Guadalajara de México (1793-1821). Notas bibliográficas (153). La Imprenta en Manila desde sus orígenes hasta 1810. Adiciones y ampliaciones (154). La Imprenta en Lima (1584-1824) 155-156-159-164. La Imprenta en la Puebla de los Angeles (1640-1821) (179). La Imprenta en Guatemala (1660-1821) (198). La Imprenta en México (1539-1821) (171-182-190-197-201-204 y 212). Catálogo de obras americanas y de algunas relativas al Oriente en su mayor parte antigua (228). Indice alfabético de los nombres de los principales personajes que se encuentran en la Colección de Documentos inéditos para la Historia de Chile (230). Un folleto de propaganda, hasta ahora desconocido, sobre la Revolución de la Independencia (241). Un incunable limeño hasta ahora no descrito. Reimpreso a plana y renglón, con un Prólogo (245). La Primera muestra tipográfica salida de las prensas de la América del Sur. Reimpresión foto-litográfica, con un breve prólogo (248). Ensayo de una bibliografía extranjera de Santos y Venerables Americanos (265). Bibliografía de don José Miguel Carrera (283). Cervantes en las letras chilenas. Notas biblio- 
gráficas (297 y 298). Notas bibliográficas sobre algunos incurables hallados en Chile. Por Fernando Bruner Prieto. Con un prólogo (302). Algo sobre los orígenes de la Imprenta en Buenos Aires. (304, 306 y 310). Quiénes fueron los autores, hasta ahora ignorados, de dos libros ingleses que interesan a América (314y 319). Biblioteca Chilena de Traductores (321-322). Diccionario de Anónimos y Seudónimos Hispanoamericanos (326-327). Catálogo breve de la Biblioteca Americana que obsequia a la Nacional de Santiago J. T. Medina (334-335). Biblioteca Hispanoamericana de la Orden de San Francisco (347). Catálogo breve de la Biblioteca Americana que obsequia a la Nacional de Santiago J. T. Medina. Tomo III. Manuscritos originales (374). Bibliografía de las Lenguas Quechua y Aymará (381). Bibliografía de la Lengua Guaraní (382).

12.-Paleografía: Documentos históricos sobre Chile, hallados últimamente en España (22). En busca de datos para la Historia de Chile (27). Vida de doña Ana Guerra de Jesús. Escrita por el P. Antonio de Siria reimpresa a plana y renglón. Precedida de un breve prólogo (330). Buenos Aires Reconquistada. Poema Endecasílabo por don Juan Ventura de Portogueda. Reimpreso a Plana y Renglón de la Edición Mexicana de 1808. Con una noticia preliminar (333). Una carta desconocida de Pedro de Valdivia (371). Cartas de Pedro de Valdivia que tratan del Descubrimiento y Conquista de Chile. (Edición facsimilar dispuesta y anotada por J. T. Medina (373).

13. Recopilaciones literarias:: Versos de José del P. Medina. Recopilados y publicados por su hijo (48). Relación en verso de un combate entre araucanos y españoles ocurrido en Chile en 1759. Por Fr. Pedro Merino de Heredia. Reimpreso de la rarísima edición de Lima de 1767 con algunas notas históricas (107). El Temblor de Lima de 1609 por el Licenciado Pedro de Oña. Edición facsimilar precedida de una noticia de El Vasauro, poema inédito del mismo autor (184). La Araucana de D. Alonso de Ercilla y Zúniga. Edición del Centenario ilustrada con grabados, documentos, notas históricas y bibliográficas y una biografia del Autor. (199, 217, 243, 251, 258). El Epítome chileno de Santiago de Tesillo. Reimpresión facsimilar a plana y renglón de la edición príncipe, con un breve prólogo (209). Imago Vechiana. Poema latino del P. Gabriel Cossart. Versión castellana de Emilio Vaïsse. (Reproducción facsimilar con una lámina (244). El primer poema que trata del descubrimiento del Nuevo Mundo. Reimpresión de la parte 
correspondiente del Carlo Famoso de don Luis Zapata, con breve prólogo biográfico y cien compendiosas notas críticas hisricas (247). Arauco Domado de Pedro de Oña. Edición crítica de la Academia Chilena correspondiente de la Real Academia Española (252). Cantos XVIII y XIX de Armas Antárticas, poema de D. Juan de Miramontes y Zuazola, reimpreso con un breve prólogo y notas críticas históricas (307).

14. Numismatica Americana: Monedas y medallas hispanoamericanas (54). Numismática argentina. Las medallas de proclamación de los Reyes de España en el antiguo virreinato del Río de la Plata. Carta abierta al señor Alejandro Rosa (66). Medallas coloniales Hispanoamericanas (124). Las Medallas Chilenas (134). Las Monedas Chilenas (137). Las monedas usadas por los indios de América al tiempo de su descubrimiento, según los antiguos documentos y cronistas españoles $(188,211$ y 232). La primera casa de Moneda que hubo en América (203). Bibliografía numismática colonial Hispano-Americana (210). Medallas de Proclamaciones y Juras de los Reyes de España en América (255). Manual ilustrado de Numismática Chilena. La Colonia (267). Las Medallas del Almirante Vernon (269). Las monedas coloniales de Chile (270). Las monadas coloniales hispanoamericanas (271). Medallas coloniales hispanoamericanas. Nuevos materiales para su estudio (272). Las monedas obsidionales de Chile (273). Las Monedas obsidionales hispanoamericanas (274). Numismática argentina (289). Las Medallas de la Revolución de la Independencia (290). Medallas Europeas relativas a América (316).

15. Lenguas aborigenes americanas: Doctrina cristiana y catecismo con un confesionario arte $y$ vocabulario breves en lengua Allentiac, por el Padre Luis de Valdivia de la Compañía de Jesús. Reimpreso todo a plana y renglón, con una reseña de la vida y obras del autor (62). Nueve sermones en lengua de Chile por el P. Luis de Valdivia de la Compañía de Jesús. Reimpresos a plana y renglón del único ejemplar conocido y precedidos de una bibliografía de la misma lengua ( 80 ). - Bibliografía de la Lengua Araucana (85). Doctrina cristiana en lengua guatemalteca, ordenada por el reverendísimo señor don Francisco Marroquín, primer obispo de Guatemala, del Consejo de Su Magestad, etc. Con parecer de los intérpretes de las sagradas religiones del señor Santo Domingo y San Francisco. Fr. Juan de Torres y Fr. Pedro de Betanzos. Reim- 
presa a plana y renglón del único ejemplar conocido y precedida de una biografía de su autor (162). Fragmentos de la Doctrina Cristiana en Lengua Millcayac del P. Luis de Valdivia. Unicos que hasta ahora se conozcan, sacados de la edición de Lima de 1607 y reimpresos en facsímil con un prólogo (261). Fray José Antonio de San Alberto. Carta a los indios infieles Chiriguanos (1790?). Nota preliminar, biografía y bibliografía de J. T. Medina (354).

16. Discursos académicos: Discurso pronunciado en el acto de inauguración de las sesiones del XVII Congreso de Americanistas por el eminente publicista José Toribio Medina, delegado de Chile (185). Discurso pronunciado en el Jockey Club por el delegado del Gobierno de Chile al Congreso de Americanistas», doctor José Toribio Medina, en el banquete of recido a los delegados oficiales extranjeros por la Facultad Filosofía y Letras (186). Sesión general celebrada por la Sociedad Chilena de Historia y Geografía el 21 de Diciembre de 1903, con el objeto de hacer entrega al señor don José Toribio Medina de la medalla anual de oro de la Sociedad. (Discursos de don Crescente Errázuriz, don José Toribio Medina y don Domingo Amunátegui Solar) (220). Cervantes americanista: lo que dijo de los hombres y cosas de América (237). Discurso leído por el señor don José Toribio Medina en contestación al del señor don Domingo Amunátegui Solar al recibirse en la Academia Chilena correspondiente de la Real Academia Española (240). Sesión general celebrada por la Sociedad Chilena de Historia y Geografía el 27 de Diciembre de 1914 con objeto de hacer entrega al señor don Gonzalo Bulnes de la medalla anual oro de la Sociedad (242). Colón y Magallanes, Discurso pronunciado en la sesión solemne celebrada por la Universidad de Chile en conmemoración del Cuarto Centerlario del descubrimiento de América (279). Palabras de agradecimiento. Discurso pronunciado en el homenaje que la Universidad de Chile rindió a don José Toribio Medina con ocasión del cincuentenario de su vida de escritor, el 25 de Agosto de 1923 (299 y 305). Discurso leído por don Ramon A. Laval en su incorporación el 30 de Noviembre de 1923 y contestación de don José Toribio Medina (301).

17. Lexicografía: Voces chilenas de los reinos animal y vegetal que pudieran incluirse en el Diccionario de la Lengua Castellana y propone para su examen a la Academia Chilena J. T. Medina (257). Glosario gramatical-lexicográfico de La 
Araucana (262). Voces Chilenas y Chilenismos incluídos en la XV Edición del Diccionario de la Real Academia Española, entresacados por J. T. Medina (331-332). Cinco obras antiguas y raras, hasta hoy desconocidas, que interesan al estudio de la filología Castellana (339). En defensa de siete voces chilenas registradas en el Diccionario de la Real Academia Española y cuya supresion se solicita por un autor nacional. Los Americanismos del Diccionario de la Real Academia Española (355-356). Nuevos chilenismos registrados en el Diccionario Manual e Ilustrado de la Real Academia de la Lengua, con indicación de Barbarismos, Galicismos, Neologismos, Vulgarismos y del mal uso de ciertos vocablos reunidos y en parte comentados por J. T. Medina (358-359). Chilenismos. Apuntes Lexicográficos (361).

18. Ensayos varios: Opúsculos varios de J. T. Medina. Reunidos y Editados por Juan Borchet (341, 342, 343, 344).

19. Autobiografía: Carta de don José Toribio Medina a don Narciso Binayán sobre los origenes y fundación de la Junta de Historia y Numismática Americana (278). Carta de don José T. Medina al Decano de la Facultad de Humanidades de la Universidad de la Plata, don Enrique Mouchet, dándole las gracias por el homenaje de que va a ser objeto en esa Universidad (300). Sesión solemene de la Facultad de Filosofía y Ciencias de la Educación, celebrada en el Salón de Honor de la Universidad de Chile, el día 6 de Octubre de 1929, con motivo de la entrega a don José Toribio Medina, de la Gran Cruz de Alfonso XII, que le fué concedida por el Gobierno Español. Anales de la Universidad de Chile, N.॰ 384 . Contiene el discurso del señor Medina (379).

Después de esta simple enunciación de títulos de libros clasificados con cierta sistemática, parecen exactas estas palabras de Altamira, cuando dijo: LLas obras históricas que sin cesar publica Medina, pudieran en rigor agruparse formando una biblioteca que llevase el nombre del autor; y en verdad aunque éste no lo haya hecho así, el público mentalmente los reúne y asocia todas bajo el sello que les imprime la actividad personal de quien las produce?.

Se ha dicho que en la obra de Medina faltó siempre una nota de belleza. Se ha repetido que la suya es como la expresión de un paisaje desértico, frío, con una igualdad de tono desesperante en su prolongación infinita. Pero no podía ser de otro 
modo. El sabía de la ausencia de una fisonomía artística en sus libros, y lo sabía con dolor. La emoción estética en la historia y en la ciencia, ante el rigorismo del método actual, la entendía como la representación de la verdad. Si Medina hubiera pensado con algún egoísmo en hacer estudios de reconstitución, de interpretación, de síntesis acabadas, de tesis subyugantes, habría agostado para otros, muchos de los elementos que generosamente entreg6. Temblaba cuando vefa cómo se iban rehaciendo cada día las conclusiones aligeradas de un Taine, de un Menéndez Pelayo, de un Mommsen y tantos otros, y no querría que su esfuerzo fuera mañana derrumbado por la crítica. En eso cifraba su orgullo y por eso trabajaba con desdén de la forma y del arte. Sin embargo, cualquiera que sean esos defectos externos, no puede negarse que hay también una gran belleza moral en este afán benedictino de buscar la verdad, y hay también belleza en el sacrificio, que tomb a veces formas heroicas de entregar, depuradas, las fuentes en que habrán de beber las generaciones futuras. Así, mientras muchos libros de arte en la composición y de belleza en el pensamiento filosófico e histórico, morirán inevitablemente por ser trabajos de interpretación de las corrientes intelectuales del momento y porque el espíritu que los inspiró paś de moda, la esencia de la obra de Medina vivirá durante siglos, porque en ella está la mejor forma de la sabiduría imperecedera, la verdad. Y seguirá siempre alimentando las más vastas creaciones de la inteligencia..G U I L L E R M O F E L I U C R U Z .

\section{S I M O N B O L I V A R}

PANORAMA DE SU VIDA, DE SU OBRA Y DE SU ACCIÓN AMERICANA (1)

4

66 OLIVAR, gran capitán, gran poeta, gran orador, todo a la vez, es la prodigiosa multiplicidad de las facultades del genio... Con estas palabras Vicuña Mackenna ha sinte tizado integralmente al Libertador. Frases ardidas de entusiasmo completan el retrato. ¡Bolívar! añade el máximo chileno. ¡Cuán

(1) Conferencia lefda en la inauguración de la Sociedad Bolivariana de Chile, en la Universidad del Estado, el 24 de Julio de 1933, día en que se cumplio el $150^{\circ}$ aniversario del nacimiento del Libertador. 